\title{
LAS CARTAS, EL SECRETO Y EL PODER EN DURANTE LA RECONQUISTA DE ALBERTO BLEST GANA
}

Letters, a secret and power in Durante la Reconquista by Alberto Blest Gana

\author{
EDSONFAÚNDEZ VALENZUELA \\ Universidad de Concepción (Chile) \\ efaundez@udec.cl \\ MARÍA LUISA MARTÍNEZ M. \\ Universidad de Concepción (Chile) \\ marmartinez@udec.cl
}

\section{Resumen}

Durante la Reconquista de Alberto Blest Gana puede ser leída como una novela en donde el secreto y el poder se entrelazan de manera profundamente significativa. Esta interrelación se constituye en el soporte de la narración, en cuyo desarrollo se entretejen los acontecimientos históricos, las intrigas amorosas y la descripción de costumbres sociales. En el despliegue de la novela hallamos inscritas las preocupaciones políticas y éticas de su autor.

Palabras clave: Novela realista chilena; género epistolar; lectura y lectores; literatura y mal.

\section{Abstract}

Durante la Reconquista by Alberto Blest Gana can be read as a novel in which a secret and power are intertwined in a profoundly significant manner. This interrelationship is constituted in the narrative support, in which the development of historical events, amorous intrigues and social customs are all interwoven. In the unfolding of the novel we can find the inscription of the political and ethical concerns of the author.

Key words: Chilean realist novel; epistolary genre; reading and readers; literatura and evil.

\section{INTRODUCCIÓN}

Durante la Reconquista, novela histórica de Alberto Blest Gana, fue publicada en París, en dos tomos, por Garnier Hermanos (1897), mientras su autor residía en Francia. El título y el subtítulo son elementos paratextuales que preorientan la recepción estética en la medida en que representan "lugares privilegiados de la dimensión pragmática de la obra, es decir, de su acción sobre el lector" (Genette, 1989, p. 12). Ellos sitúan espacial y temporalmente (título) y declaran la filiación al subgénero de las novelas históricas (subtítulo) que producen "la ilusión de espacializar un tiempo bloqueado" (Jitrik, 1995, p. 15) y pretenden desplegar un saber histórico "capaz de restablecer el lazo entre lo colectivo y lo individual" (Jitrik, 1995, p.16). Durante la Reconquista se estructura a partir de las 
claves estilísticas de las ficciones realistas, cuyo modelo lo entrega la obra de Honoré de Balzac; y de las novelas históricas del escritor escocés Walter Scott, quien erige las bases del subgénero en el contexto del romanticismo literario europeo. Blest Gana produce su novela histórica, por consiguiente, asumiéndose como heredero de las ficciones novelescas romántica y realista; y lo hace con clara conciencia del carácter híbrido de las novelas históricas, mezcla siempre "de invención y realidad [pero cuyo resultado] no es una obra correspondiente a la historia, sino a la literatura, es decir, una obra de ficción" (Mata, 1998, p. 14-15). Su novela reúne acontecimientos imaginarios con otros auténticos del pasado histórico y, como ocurre con las escrituras novelescas decimonónicas, se apodera así de un tiempo paradigmático, "desplazando al registro de la ficción literaria hechos y personajes históricos, y poniendo en el escenario o en la página situaciones que fueron reales o que son presentadas como reales" (Chartier, 2007, p.40).

La inclusión de acontecimientos y personajes históricos permite a los comentadores de Durante la Reconquista sostener que su autor elabora una novela histórica (Alegría, 1978; Lastra, 2009)1, histórica social (Silva, 1955)² o una novela histórico costumbrista en la que se advierte una matriz textual recurrente en la escritura de Blest Gana: los triángulos eróticos (Araya, 1987) ${ }^{3}$. Estimamos que las apropiaciones del discurso histórico y de la memoria, por un lado, buscan afectar la recepción estética para que los lectores de la época de publicación de la novela concreticen el texto desde una perspectiva realista y, por otro lado, determinan la producción de sentidos del texto literario a partir de la autoridad que reside en un saber histórico fundante de una

\footnotetext{
${ }^{1}$ Fernando Alegría escribe: “Durante la Reconquista, reputada como la obra maestra de Blest Gana, es acaso la mejor novela histórica que se escribió en Hispanoamérica durante el siglo XIX" (s/f: p. 94). Pedro Lastra, en su palabra liminar para la edición de Durante la reconquista dispuesta y anotada por Iván Jaksic y Juan Durán Luzio, destaca una de las ideas que Blest Gana desarrolla en su conocido discurso de incorporación a la Facultad de Humanidades de la Universidad de Chile, el 3 de enero de 1861: "Sin remontarnos al eterno batallar de la conquista, encontramos en los fastos de la guerra de la independencia variadas e interesantes peripecias, heroicas acciones, escenas animadas, que el novelista puede combinar con felicidad para la ejecución de amenísimas novelas". Lastra advierte que "resulta imposible no ver en aquella referencia a los 'méritos de la novela histórica' algo más que un esbozo de la novela que publicaría en 1897” (2009, p. 261).

${ }^{2}$ Raúl Silva Castro señala que Durante la Reconquista “es una perfecta fusión de verdad e imaginación, lo más logrado que se ha producido en el ramo de la novela histórica" (1955, p.254), que refleja "los sentimientos colectivos de un pueblo en lucha por su libertad" (1955, p.272). Señala cinco sucesos históricos que son ficcionalizados en la novela: a) la entrada triunfal en Santiago del general Mariano Osorio (1814); b) la batalla de Rancagua (1814); c) "la prisión de patriotas en Santiago la noche del 8 al 9 de noviembre de 1814, su encierro en la cárcel y la sublevación que culminó en la matanza del 6 de febrero de 1815” (1955, p. 251); d) el viaje a Chile de José Antonio Álvarez Condarco (1816); e) el asalto a Melipilla (1817).

${ }^{3}$ Blest Gana, señala Araya, "tomó un trozo de la historia de Chile y lo narró con la técnica y la visión de mundo que había ensayado en sus novelas costumbristas anteriores. Es decir, creó así una obra literaria de carácter histórico que era una novel y no un romance. Dicho de otra manera: creó una novela histórica costumbrista" (1987, p. 183).

170 | Alpha № 53 (Diciembre 2021) PÁGS. 169-189. ISSN 07 16-4254
} 
determinada comunidad. Erigen, además, un territorio objetivo y reconocible para el lector, quien no verá perturbada la ilusión de realidad, de autenticidad y de verosimilitud, por la inclusión de intrigas amorosas y personajes fictivos ${ }^{4}$, que anudan el sistema de relaciones reveladoras de los conflictos ideológicos, las tensiones sociales, las relaciones de poder, la violencia colonial, los sueños independentistas, las negociaciones y los afectos que singularizan, entre otros aspectos, la vida social durante el período de la reconquista (1814-1817), signado por los gobiernos de Mariano Osorio y Casimiro Marcó del Pont. Es precisamente la vida que no ilumina el discurso histórico, centrado en las hazañas heroicas del proceso de la independencia de Chile, la que pretende hacer visible Blest Gana en su novela a partir de apropiaciones de la memoria y elaboraciones de la imaginación literaria. Por lo mismo, Hernán Poblete destaca que Durante la Reconquista logra "captar la existencia diaria, cotidiana, vulgar, del hombre que vive una circunstancia histórica. Y esto elimina por completo las posibilidades gallardas, como ocurre en la realidad: el personaje -real o novelesco- no sabe en qué momento es personaje histórico" $(1995$, p. 218). Al lado de personajes reconocibles en términos históricos, encontramos personajes infames, sin gloria y esplendor. Estos van a incidir en el carácter distintivo de la novela, que está regida, como señala Guillermo Gotschlich, por "la desconstitución de la figura épica o degradación del héroe", que permite la aparición, siguiendo a Luckács, de un héroe mediocre como Abel Malsira (1991, p.31), muy diferente a Manuel Rodríguez, el héroe por excelencia del período ficcionalizado; fecundo en ardides, valiente, mesurado y elusivo.

La novela de Blest Gana es fiel al legado literario de Walter Scott, en la medida en que Durante la Reconquista es, sin ninguna duda, una novela ilusionista, caracterizada, entre otros aspectos destacados por Kurt Spang (1998), por la ilusión mimética de la síntesis entre ficción e historia (concebida como un continuo), creadora de un "mundo total y autárquico" (1998, p.69); por la presencia de un narrador omnisciente, implicado y comprometido con una determinada perspectiva de la historia; por el despliegue de un tiempo paradigmático en la evolución de una nación; por la configuración de la naturaleza como un territorio simbólico esencial; por la importancia que asume la descripción y una tendencia a lo melodramático. Durante la Reconquista, y esto marca la singularidad de la novela, es también infiel a la novela histórica ilusionista, Por cuanto se aproxima a la novela histórica antiilusionista ${ }^{5}$, si examinamos la dimensión de los personajes. La novela de Blest

\footnotetext{
${ }^{4}$ La recepción de la novela experimenta inevitables variaciones de acuerdo con las características y expectativas de los lectores, así como también por su distancia temporal respecto de la época de publicación de la novela. Domingo Amunátegui Solar en Bosquejo histórico de la literatura chilena (1915) critica duramente la falta de verosimilitud de las intrigas amorosas que reúnen a Hermógenes Laramonte con Trinidad Malsira y a Abel Malsira con Luisa Bustos. Esto, unido a la falta de rigor histórico, sugiere el historiador liberal, debilita la novela. ${ }^{5}$ Kurt Spang en "Apuntes para una definición de la novela histórica" señala: "En la novela de tipo ilusionista se enaltece el individuo y las decisiones y motivaciones particulares mientras que en "la otra novela histórica" [la antiilusionista] juegan un papel mucho más importante los grupos sociales e ideológicos, las instituciones,
} 
Gana no celebra las grandes hazañas de héroes individuales capaces de producir cambios sociales y transfigurarse en modelos a imitar, por lo que la figura de Manuel Rodríguez, si bien es destacada, de ninguna manera es central. El fracaso de los proyectos individuales de los héroes novelescos (Luisa Bustos y Abel Malsira), cifrado en su muerte melodramática, puede ser leído en este sentido. Durante la Reconquista, como sucede en las novelas históricas antiilusionistas producidas desde el siglo XIX hasta nuestros días, permite que ingrese al mundo ficcionalizado "la intrahistoria del mundo cotidiano, las personas de estamentos bajos y las actuaciones de poca monta [donde] son las masas o por lo menos los grupos los que mueven el mundo, ya no el individuo aislado" (Spang, 1998, p.71) ${ }^{6}$.

Durante la Reconquista resalta un momento clave en la configuración de la memoria y, por tanto, en la construcción de una idea de chilenidad. La revisitación del pasado supone una escritura, pero también una lectura de ese pasado, que es coherente respecto del pensamiento de los intelectuales liberales, quienes cifran en la independencia de Chile las claves del ser colectivo y nacional: acontecimiento de superación de la dominación colonial y de proyección de una nueva comunidad: territorio mítico y fundacional en donde los sueños del porvenir aún se encuentran en estado de latencia ${ }^{7}$. Blest Gana, si bien adhiere a una visión liberal de la independencia, no se desentiende de lo que Mabel Moraña denomina "las dinámicas sociales que

se cuestiona el papel del individuo insistiendo en sus condicionamientos o incluso determinaciones. Los cambios sociales no son provocados tampoco por los individuos, sino por las masas y los sistemas" (Spang, 1998, p.79).

${ }^{6}$ Un problema de gran interés en la novela, que no podemos desarrollar en este artículo, es el de los personajes populares. Su análisis ha ido cambiando debido a la aparición de nuevas formas de leer la novela. En términos generales, se advierte, en las primeras interpretaciones de la novela (por ejemplo, Melfi, 1938), una imagen positiva respecto del tratamiento de la masa popular y del roto, lo que variará en trabajos recientes, como los de Álvaro Kaempfer (2006), para quien los personajes populares y subalternos están condenados al disciplinamiento o la exclusión: "Cámara es, precisamente, un dispositivo que opera, al menos, en dos niveles. Por un lado, sutura la construcción narrativa de una nacionalidad proyectada como relato de emancipación que testimonia la hegemonía y liderazgo de las élites criollas. Por el otro, Cámara es el habla corregida que hace de la subalternidad el signo legible de lo popular en una narrativa de chilenidad postulada como relato de orden a fines del siglo XIX [...] la emergencia subalterna de Cámara sugiere su eliminación y disciplinamiento tras el retorno de los héroes" (2006, p.157). La misma perspectiva crítica puede advertirse en Antonia Viu (2011) y Sebastián Schoennenbeck (2013).

${ }^{7}$ Alfredo Jocelyn-Holt Letelier en La independencia de Chile. Tradición, modernización y mito se refiere a las ideas que desarrollan los historiadores liberales y conservadores acerca de la independencia de Chile. Señala, a grandes rasgos, que para los primeros este acontecimiento histórico significa un quiebre con el pasado colonial y el surgimiento de una idea de progreso que despliegan instituciones inspiradas en la doctrina liberal, que son significativas en la articulación de una nación republicana; para los segundos, la independencia y la doctrina liberal no son decisivas en la "institucionalidad chilena del siglo XIX", pues la "restauración" se funda en valores hispánicos y en un carácter autoritario, rasgos evidentes del régimen portaliano. Es interesante en la tesis de Jocelyn-Holt advertir las zonas de intercambio que se producen entre las escuelas históricas liberales y conservadoras en Chile, problema que no es pertinente desarrollar en estas páginas.

172 | AlPHA No 53 (DiCIEMBRE 2021) PÁGS. 169-189. ISSN 07 16-4254 
acompañan la emancipación [y] se resuelven más bien en relaciones ambiguas, híbridas y variables entre culturas, ideologías y sectores sociales" (2014, p. 53); por lo mismo, su novela, a partir de algunos personajes y sus relaciones, erosiona la perspectiva binaria de la retórica de la emancipación ${ }^{8}$. La escritura-lectura de la memoria del tiempo de la reconquista española y de la resistencia patriota permite, en la novela de Blest Gana, la emergencia de nuevos sentidos, que pueden hacer aflorar sentimientos, convicciones, lealtades y energías debilitados en el Chile de fines del siglo XIX. El país ha crecido económicamente y se ha potenciado en el escenario internacional, luego de la Guerra del Pacífico, pero parece olvidar las lecciones del pasado, sin las que no es posible disponer de las vías de orientación necesarias para abordar los problemas del presente y rescatar los sueños liberales e ilustrados, tan lejanos al tiempo de la escritura de la novela ${ }^{9}$. Blest Gana, en efecto, asimila esta idea, por lo que es posible advertir aún la presencia de los ideales romántico-liberales y de la idea de función social de la literatura, capaz de afectar la realidad extratextual; pero su visión carece del optimismo, por ejemplo, que encontramos en novelas como Martín Rivas, donde, siguiendo a Doris Sommer (2004), se aprecia una síntesis esperanzadora entre eros y nacionalismo. En Durante la Reconquista los proyectos deseantes de los héroes novelescos, como ya indicamos, fracasan. Son reflejos del proyecto de nación, ilustrado y liberal que, según Jaime Concha, Blest Gana ya advierte en 1857 a partir de las (incomprensibles) alianzas entre liberales y conservadores (1977, p. XXII), y, como se sabe, se hace indudable luego de la guerra civil de 1891 y la muerte de José Manuel Balmaceda. Blest Gana estima que las energías del presente no permiten la revitalización de los sueños del porvenir; por eso es que su escritura establece un bloque intenso y productivo con la memoria del pasado, donde la idea de una comunidad heroica se impone respecto de las hazañas y las miserias de la vida individual. Blest Gana re-crea la memoria del pasado, desengañado de la factibilidad de la instalación del proyecto liberal en Chile,

\footnotetext{
${ }^{8}$ Así pueden interpretarse, por ejemplo, las negociaciones de la élite criolla de Santiago, compuesta por los pusilánimes Francisco Carpesano, Manuel Cardenillo y José María Reza, quienes terminan siendo considerados, en una clara alusión de Blest Gana a la mentira que encubre la historia oficial y las negociaciones políticas que afectaron los sueños de transformación social de su generación, "víctimas ilustres de la tiranía colonial" (1946, II, p.511). Beno Carpesano, en la carta enviada a Abel Malsira, ilumina esta situación, que obviamente excede el tiempo de la ficción novelesca y remite a las tensiones entre liberales y conservadores del siglo XIX en Chile. Carpesano se refiere a las fiestas organizadas por Marcó del Pont, en las que no faltaban "muchos chilenos de los que les gusta tener un amo aquí y otro en España" (1946, II, p.271-272). Por último, la relación amorosa entre el coronel español Hermógenes Laramonte y la criolla Trinidad Malsira, que, aunque está condenada al fracaso, le permite al novelista, como sostiene Laura Hosiasson, ampliar "las fronteras hacia un tejido más complejo sobre el cual se iría forjando lo nacional"' (2017, p.243).

${ }^{9}$ Gotschlich escribe respecto de los sueños del porvenir y la idea de historia de Blest Gana: "A distancia no despreciable de la vigencia del momento romántico, el código de esta tendencia mantiene todo su significado para Alberto Blest Gana, en el sentido de considerar la función de la historia como camino de reconstitución moral e institucional, armonizadora naturalmente del destino de los pueblos y la humanidad" (1991, p.57).
}

ALPHA № 53 (DiCIEMBRE 2021) PÁGS. 169-189. ISSN 07 16-4254| 173 
por lo que su novela puede ser comprendida como "el responso a las ideas liberales de su autor”' (Concha, 1977, p. XXII). En Durante la Reconquista, el pensamiento utópico pervive, a pesar del desencanto, como huella o rastro de otro tiempo, por lo que, si se pretenden encontrar las semillas de la esperanza y del porvenir, los lectores deberán escarbar en los acontecimientos revividos en la ficción novelesca.

\section{LAS CARTAS DE AMOR}

Las cartas en el siglo $\mathrm{XIX}^{10}$, como bien sintetiza Carolina Navarro, son "el medio social que dispuso sus recursos discursivos para la elocuencia sobre la comunión familiar, amistosa y amorosa en el abordaje de lo íntimo" (2017, p. 61) ${ }^{11}$. Blest Gana captura ese dispositivo escritural, cuyo uso es cada vez más habitual en el siglo XIX, entre otros motivos, por el afán de reafirmación de las subjetividades individuales, por el incremento de la migración y por el aumento del índice de alfabetización. Este aspecto, sumado al lenguaje sencillo y sincero de la carta de amor, intensifica el efecto de realidad de la novela, en la medida en que contribuye a la legibilidad, la familiaridad y la visibilidad de la vida personal y cotidiana que caracterizan el estilo de la escritura realista. Las cartas, según indica Bajtin en "El problema de los géneros discursivos", pueden considerarse dentro de los géneros discursivos primarios (simples) y la novela dentro de los géneros discursivos secundarios (complejos); desde esta perspectiva, la novela absorbe y reelabora cartas, las que conservan "su forma e importancia cotidiana tan solo como partes del contenido de la novela, participan de la realidad tan solo por medio de la totalidad de la novela, es decir, como acontecimiento artístico y no como suceso de la vida cotidiana" (1992, p. 250). El estudio de las cartas comprendidas como acontecimientos artísticos, resultado de la apropiación que efectúa un discurso secundario complejo como la novela, permite leer Durante la Reconquista como una novela en

${ }^{10}$ Darcie Doll Castillo en "La carta privada como práctica discursiva. Algunos rasgos característicos" (2002) realiza una síntesis de las principales características de la carta privada. Los once rasgos que destaca, en su riguroso artículo, son los siguientes: la carta como diálogo diferido; la carta como género discursivo primario; la carta como poseedora de un formato fijo y definido en oposición a una amplitud indefinida de contenidos; los sujetos de la carta definidos por un contrato epistolar; las cartas exhiben las marcas de la situación de enunciación y de recepción; las cartas poseen un destinatario definido y caracterizado; las cartas presentan una tendencia del sujeto a la autorreferencialidad; la carta es un discurso orientado hacia el discurso del otro; la carta posee una tendencia a la autorreferencia, por lo que atestigua su "acto de existencia"; la carta ostenta un mundo de sobreentendidos; la carta transita por la frontera entre lo literario y lo no literario, entre lo privado y lo público.

${ }^{11}$ Debe tenerse en consideración que el discurso epistolar amoroso "no solo es expresión de enamoramiento, sino también sostén vital en etapas críticas para relaciones de pareja no permitidas u obstruidas" (Salinas, 2006, p.73). De ahí su relevancia en la novela que comentamos.

174 | Alpha No 53 (Diciembre 2021) PÁGS. 169-189. ISSN 07 16-4254 
donde las cartas imaginarias son un elemento esencial de su construcción y, consecuentemente, valiosas respecto de la producción de sus sentidos ${ }^{12}$.

Es relevante destacar que las cartas imaginarias de tema amoroso adquieren una condición particular en el entramado novelesco. Básicamente, el signatario proyecta su subjetividad en la carta y espera la lectura del destinatario, quien, además de concretizar los sentidos de la carta, debe responder con otra carta, configurándose de este modo el circuito comunicativo sobre la base del diálogo y del pacto epistolar, que, en la novela que nos ocupa, se sustentan en el secreto de amor. El narrador, sin embargo, es un lector no previsto en la carta, que conoce el contenido de la misma y lo enseña a los lectores, quienes experimentan en secreto el placer que genera conocer intimidades que abandonan la esfera de lo privado. La función del narrador, desde este acceso, consiste en traicionar el secreto de las cartas de amor. No puede ser de otro modo, pues la literatura, como señala Michel Foucault, no ha cesado de hacer visible desde el siglo XVII "lo que es más difícil de captar, lo más oculto, lo que cuesta más trabajo decir y mostrar, en último término lo más prohibido y lo más escandaloso [... ] Mas que cualquiera otra forma de lenguaje la literatura sigue siendo el discurso de la 'infamia', a ella le corresponde decir lo más indecible, lo peor, lo más secreto, lo más intolerable, lo desvergonzado" (1996, p. 137). La novela revela lo más secreto de personajes dominados por una pasión amorosa. Pero también, y como veremos más adelante, en el mundo ficcionalizado el secreto de las cartas de amor se propaga, como por una especie de contagio, hacia los otros, describiendo así un rasgo singularizador del secreto contenido en las cartas de amor. Las cartas, por tanto, parecieran tener una existencia que no queda supeditada a la presencia del emisor y del receptor, quienes participan en una dialéctica de presencia y de ausencia destacada por Tzvetan Todorov (1971) ${ }^{13}$, Patrizia Violi (1987) y Anne Carson (1998), por lo que emisor y receptor, habitantes de un silencio o de una ausencia, devienen construcciones imaginarias en el espacio de la carta de amor.

Las cartas de tipo amoroso posibilitan el despliegue del yo y, en consecuecia, de posiciones de deseo. La lectura de cartas, desde esta perspectiva, sustituye en Durante la Reconquista la lectura de textos literarios (novelas o poemas), que opera con frecuencia

\footnotetext{
${ }^{12}$ Seguimos en este punto los planteamientos desarrollados por Tzvetan Todorov en su análisis de las cartas que integran la novela Las amistades peligrosas (1782) de Pierre Choderlos de Laclos, que se encuentra en su libro Literatura y significación (1971).

${ }^{13}$ Todorov escribe: "He aquí por qué, tratándose de las cartas, no podemos dejar de lado a los elementos del proceso de enunciación. Ninguna palabra evoca una imagen de su emisor (ni tampoco de su receptor) tan rica como la del texto escrito: precisamente porque a su emisor y a su receptor se les supone ausentes o desconocidos. La palabra no evoca la realidad a la que se refiere; las palabras orales son la muerte de las cosas; pero se conoce desde siempre esta propiedad de la literatura, de las combinaciones de letras, de recrear, de instaurar una realidad que no tiene ninguna otra existencia. Ausencia y presencia no designan la una a la otra; y Artaud hablaba ya de "un silencio formado por pensamientos que existe entre los miembros de una frase escrita"' (1971, p. 34).
} 
como mediadora del deseo en la escritura de Blest Gana ${ }^{14}$. Las cartas de amor forman parte de las escrituras del yo, las que, si seguimos a Michel Foucault, experimentan a partir del siglo XVI en Europa, como efecto de la mayor relevancia que adquieren los discursos autobiográfico y confesional, una metamorfosis y proliferación importantes: "en el contexto simultáneo de la Reforma, y la vuelta, precisamente, a formas y preocupaciones éticas bastante similares a las de los siglos I y II, constatamos también la renovación del género de la nota, el diario íntimo, el diario de vida, el diario de a bordo de la existencia, y además [de] la correspondencia" (2005, p. 339). Las cartas de amor permiten la relación de uno consigo mismo y, por tanto, hacen visible una verdad sobre el yo, de ahí su carácter autorreferencial y confesional. El deseo emerge en las cartas portadoras de una verdad sobre el yo, sin mediaciones aparentes, lo que trae como correlato la enunciación de una pasión amorosa verdadera, lejana a los deseos que surgen sobre la base de la vanidad y del amor al dinero, que Blest Gana atribuyó al imperio de la aritmética en el amor. Nos interesa comentar en estas páginas, fundamentalmente, las relaciones epistolares que le dan forma a las intrigas amorosas que se establecen entre Hermógenes Laramonte y Trinidad Malsira, y entre Luisa Bustos y Abel Malsira, pues en ellas advertimos, entre otros aspectos, estrategias de re-construcción del yo, de resistencia a los poderes hegemónicos, y el despliegue de pasiones amorosas que se presentan liberadas de las mediaciones que condicionan, por ejemplo, los deseos de Violante de Alarcón, "coqueta y ambiciosa" (Blest Gana, 1946, I, p. 52) $)^{15}$, adoradora del oro, quien busca, mediante un matrimonio ventajoso, "volver a España, su sueño dorado" (I, p. 255).

Abordamos con interés las cartas producidas por personajes femeninos. La carta amorosa, cuyo emisor es una mujer, está lastrada por un estereotipo de género en las ficciones realistas del siglo XIX. La novelística de Blest Gana no se encuentra desvinculada de esta relación de fuerzas que condena a la mujer al espacio de intimidad, privado y secreto, que abre, al interior del lenguaje, la carta de amor. Estimamos, sin embargo, que su estudio posibilita amplificar los sentidos respecto de la significación de las cartas ficcionales, escritas por personajes femeninos, en las narraciones realistas decimonónicas, tarea que permitirá, junto con los trabajos que rescatan y reflexionan sobre la escritura epistolar de mujeres en la vida cotidiana (por ejemplo Morales, 2003; Vergara, 1987; Navarrete, 2017), construir una imagen del lugar y los sentidos de las cartas dentro del marco de las múltiples escrituras del yo del período.

\footnotetext{
${ }^{14}$ Así puede advertirse en personajes como, solo por citar algunos, Abelardo Manríquez, lector de Abelardo y Eloísa en El ideal de un calavera; Mariluán, lector de La Araucana en Mariluán; Edelmira Molina, lectora de folletines románticos en Martín Rivas; Matías Cortaza, lector de Robinson Crusoe y de El chileno consolado en su presidio en El Loco Estero.

${ }^{15}$ De ahora en adelante, las citas de Durante la Reconquista irán acompañadas con los números de tomo y de página. Ver referencias bibliográficas.
}

176 | AlPHA № 53 (Diciembre 2021) PÁGS. 169-189. ISSN 07 16-4254 


\section{LAS CARTAS DE AMOR EN DURANTE LA RECONQUISTA}

Las cartas son un recurso escritural frecuente en la novelística de Alberto Blest Gana. Las encontramos desde Una escena social. Novela orijinal chilena (1853) hasta Gladys Fairfield (1912). Durante la Reconquista es una de las novelas en donde las cartas, varias y heterogéneas, cobran una significación especial. Hay cartas de amor que inciden en las intrigas que reúnen a Trinidad Malsira y Hermógenes Laramonte, a Violante de Alarcón y Abel Malsira, y a Luisa Bustos y Abel Malsira; cartas como la que envía Laramonte a Clarisa Bustos para aceptar la exigencia matrimonial que ella plantea; cartas informativas como la de Beno Carpesano a Abel Malsira o la de José Robles a Manuel Rodríguez, en las que se comunican acontecimientos relevantes; cartas que presentan información falsa como la de Violante de Alarcón a Luisa Bustos, donde la española se justifica y explica el propósito de la compra de la hacienda "Los Canelos", o la que escribe Manuel Rodríguez a Juan Argomedo en el episodio del robo del pasaporte; la carta formal con la que Luisa Bustos solicita una entrevista a Laramonte; las tranquilizadoras cartas que escribe Alejandro Malsira a Clarisa Bustos, su esposa, desde la prisión; la carta, signada por el amor y el sufrimiento, que escribe Clarisa Bustos a Alejandro Malsira; la carta que dirige Abel Malsira a su hermana para contarle de su apoyo al matrimonio con Laramonte, la muerte del padre, su deseo de venganza y su necesidad de huir de Santiago; y la carta que dirige Marcó del Pont a Violante de Alarcón, en la que, junto con afectados requiebros amorosos, cumple el deseo de la viuda, quien solicita la libertad de Abel Malsira.

Merecen atención las cartas que configuran la trágica pasión amorosa del coronel realista Hermógenes Laramonte y Trinidad Malsira ${ }^{16}$. Su proyecto amoroso, antes de su definitivo fracaso, expresado en el viaje de Laramonte a Perú y en la muerte de la joven Malsira, enfrenta varios obstáculos, tales como la oposición de la familia Malsira, la reclusión de Trinidad en un convento (dispositivo de poder que sustituye al dispositivo disciplinario familiar) y el asedio de San Bruno, quien desea vengarse de Laramonte. La correspondencia amorosa se intensifica debido a estos obstáculos que separan a la pareja.

La carta que escribe Hermógenes a Trinidad, y forma parte del capítulo XI del tomo I de la novela, es un juramento de amor, por lo que es evidente su carácter autorreferencial, y es una solicitud de entrevista clandestina, que aclara el objeto y destino de la sentimentalidad del emisor, a la vez que exige una contestación. El narrador ejerce un control sobre este episodio, en la medida en que termina de referir el contenido de la carta y anticipa la recepción de la destinataria. Esta estrategia es recurrente en la novela e

\footnotetext{
16 Téngase presente que la pasión amorosa solo surge después de que Hermógenes Laramonte ha podido superar su deseo mediatizado por la vanidad y la adoración del oro, móviles de su acercamiento inicial a Trinidad Malsira.
} 
incide en la construcción del lector ficcional (implícito), que busca orientar la recepción de los lectores reales:

el efecto del agua del cielo en un tiempo agostado por el sol de verano [...] sus esperanzas marchitas se alzaron de nuevo como flores gallardas [...] la separación entre los que se aman es una especie de muerte transitoria, que desgarra el pecho y anonada con desconsuelos que parecen eternos. Pero es una muerte con resurrección, con el milagro inefable de la nueva presencia del ser querido (I, p. 152).

La recepción de la carta revive el amor-pasión en Trinidad Malsira. Hace posible, en el plano de la intimidad sentimental, una relación dialéctica, propia del discurso amoroso epistolar, que se resuelve en la síntesis entre muerte y resurrección: la muerte que produce el distanciamiento de los amantes (ausencia) y la resurrección que surge con la esperanza del reencuentro (presencia). La correspondencia epistolar se convierte así en el territorio adecuado para el despliegue del deseo amoroso, el diálogo imaginario de los amantes ausentes y la síntesis entre los heterogéneos presencia y ausencia (Violi, 1987). La carta, como escribe Emily Dickinson, "es un goce terrenal / que los dioses ignoran" (2001, p. 279), pero el gozo nunca se presenta desconectado del sufrimiento (Carson, 2015). Permite también la construcción de las subjetividades de los amantes, en la medida en que la palabra ilumina las señas de los rostros que se reconstruyen y se miran arrastrados por una energía amorosa que en la escritura de Blest Gana deviene siempre irresistible. Debido a que la escritura y la lectura son mediadores en la construcción de dichas subjetividades, estas resultan ser siempre co-creaciones del autor y del destinatario de la carta, quien participa activamente en la producción de sentidos a partir de las concreciones estéticas que realiza ${ }^{17}$. Hay otra dimensión que resulta interesante. Se trata de las relaciones entre el discurso epistolar y el poder. El narrador de Durante la Reconquista señala algo que nos permite reflexionar desde esta perspectiva:

Llegar a escribirle había sido vencer dificultades infinitas, capaces de desalentar a cualquiera que no fuese una chica enamorada. Sustraer papel y pluma del escritorio de su padre; escribir a hurtadillas, en los momentos que pudo burlar la vigilancia de doña Clarisa; confiar al papel, con enfadosas dudas ortográficas, con el pudor de una educación casi monacal, esas palabras imponentes que una chica piensa, pero que no se atreve a pronunciar, palabras que todas conducen a decir "amor", como todo camino lleva a Roma, fue para Trinidad una obra inmensa. Y a medida que pasaba el tiempo, el papel le quemaba el seno y le torturaba el pensamiento. " ¿Si habría dicho demasiado? ¿Qué pensaría Hermógenes de ella?’ Por momentos se figuraba todo lo contrario. Las frases que le repetía su memoria eran confusas y

\footnotetext{
${ }^{17}$ Seguimos en este punto los planteamientos teóricos de Wolfgang Iser desarrollados en El acto de leer (1987).
} 
frías. "¿Si él fuese a figurarse que no lo amaba?” ¡Un mundo de angustias contradictorias! (I, p. 156).

La escritura de la joven Malsira implica una transgresión, una resistencia al dispositivo de poder familiar. En el nivel más visible la transgresión es ideológica, pues Laramonte es un soldado realista y la familia Malsira es leal a los ideales libertarios de los patriotas, lo que perturba el orden binario de la retórica y de la ideología de la guerra. En otro nivel, la transgresión de Trinidad es política, pues la escritura le permite desplegar y hacer visibles su intimidad y sus deseos, al mismo tiempo que resiste los mandatos del poder familiar y patriarcal. El acto de escribir está signado, en consecuencia, por pequeños crímenes en el ámbito familiar, que, obviamente, trascienden hacia la esfera del poder estatal. La acción de sustraer papel y pluma al padre ilumina, además de la preocupación de la signataria por el aspecto material de la carta, la prohibición de los medios necesarios para que la mujer produzca objetos escriturales, así como también la transgresión a la ley del padre, quien ejerce el dominio de la cultura letrada; burlar la vigilancia "policial" de doña Clarisa, la madre, sugiere una posición distinta de la generación a la que pertenece Trinidad respecto de las costumbres patriarcales; escribir, al parecer, con faltas de ortografía, intensifica el distanciamiento de los poderes hegemónicos, en este caso, de la lengua políticamente dominante; escribir, a pesar del pudor, significa vencer las barreras que impone un sistema educacional conservador, cuestionable en sus alcances formativos. Las interrogaciones que formula la signataria de la carta envían a la autorreferencial de un sujeto angustiado y a una reflexión acerca de la escritura. Puede advertirse que la novela de Blest Gana no considera que el dispositivo carta deba circunscribirse solo a los ámbitos de la autorreferencialidad, de la figuración del yo como un otro que emerge en la escritura, del diálogo diferido entre los amantes que habitan la zona indeterminada que se abre entre la ausencia y la presencia físicas que se actualizan, entre otros aspectos, en la red que se establece entre el emisor, el mensaje y el destinatario. El dispositivo carta se conecta problemáticamente con otros dispositivos sociales de poder. Así lo sugiere el mismo narrador de la novela cuando nos plantea conexiones y cortocircuitos entre la carta y los dispositivos de poder familiar, escuela, iglesia, Estado.

La carta de respuesta que escribe la joven Malsira es un objeto para ella sagrado, portador de "un gran secreto de amor" (I, p. 179), que quema su seno y tortura su pensamiento, más todavía por las dificultades que tiene para que esta llegue a su destinatario: “¿Cómo entregar la carta a Hermógenes?” (I, p. 177). La novela sugiere con esta imagen que la carta es el cuerpo erótico y secreto de la escribiente, pero también la carta es su interioridad perturbada por un secreto y un deseo que afectan el orden establecido. El sujeto femenino se transfigura así en una figura fuera de la ley, condenada a ser perseguida por el poder familiar y estatal mientras perviva en ella el "fuego que nada puede apagar y que lleva por doquiera el incendio voraz de su llama irresistible" (I, p. 
185). Sugiere además que las dimensiones autorreferencial y dialógica de la carta de amor son evidentes y primordiales, pero que no debe desestimarse la materialidad de la carta, objeto que quema y tortura, igual que el deseo en el cuerpo de la enamorada, ni, como hemos destacado, el sistema de relaciones de poder del que la carta participa; aspectos que resultan de suma importancia al momento de establecer la significación de las cartas que contienen la huella de los amantes en el espacio novelesco.

Hay otra carta que dirige Trinidad a Laramonte, sin su firma y escrita en el mismo escritorio del joven coronel, utilizando su papel y pluma (reiteración de una escena que revela cómo la práctica de la escritura del yo femenino implica una apropiación simbólica de la cultura letrada), cuando este se encontraba herido. La carta indica: "le escribo estas pocas líneas temblando. Espero que usted encontrará modo de contestarme con su asistente si lo cree hombre de confianza [...] Yo iré a la huerta varias veces en el día para ver si hay algo" (II, p. 15). Llama la atención la síntesis que se establece entre escritura y temblor, que, además de señalar el bloque intenso que se actualiza entre escritura y cuerpo, revela el estado interior de la signataria a partir de marcas de autorreferencialidad; asimismo, la carta pide al otro una respuesta escrita y secreta: una carta arrojada en la huerta de su casa: una carta que ya tiene en sí misma las huellas de una deriva y de una destinación desconocidas. En otras cartas, Trinidad escribe: "Vuelvo a jurarle que mi vida le pertenece. Lo seguiré a usted cuando quiera y donde quiera" (I, p. 337); "Nuestra suerte queda en manos de usted. Yo aceptaré la resolución que usted tome, sin vacilar. Cualquiera que ella sea, en mi corazón vivirá usted siempre, y nadie, ni obstáculo ninguno, me impedirá seguirlo cuando usted me llame" (II, p. 173). El narrador señala que la carta casi no expresa sentimientos; estos sin duda se encuentran implícitos o se constituyen en sobreentendidos. También indica que "la carta vibraba de resolución ardiente, una expansión poderosa de aquella alma oprimida" y que "tocaba en el alma varonil de Laramonte la cuerda más sensible" (II, p. 173): la entrega total de la amada: "Vuelvo a jurarle que mi vida le pertenece". Es la responsabilidad solicitada al otro el contenido secreto de las breves cartas de Trinidad. La sentimentalidad queda suspendida como sobreentendido y emerge una velada interpelación ética: un llamado, una urgencia y una exigencia de responder -ya no solo con palabras-con responsabilidad al sacrificio por amor. Responsabilidad que acoge, en definitiva, el coronel español, también con una carta. Nos referimos a la carta enviada a Clarisa Bustos en la que acepta "no volver a combatir en este país contra ninguna fuerza armada de Chile desde el día en que sea el esposo de la expresada señorita" (II, p. 176). Y no puede ser de otro modo, porque la pasión amorosa de Trinidad Malsira y Hermógenes Laramonte, que es exorcizada en el entramado novelesco, solo existió en los territorios imaginarios de la carta de amor. 


\section{LA CARTA, EL SECRETO Y EL PODER}

Vicente San Bruno, mezcla de fraile fanático y militar sanguinario, y, por tanto, personaje que aúna los dos poderes, eclesiástico y militar, del imperio colonizador, intercepta las cartas de los amantes, mientras Trinidad se encuentra recluida en un convento. San Bruno captura las cartas y accede al secreto de amor, utilizando como ayudantes al portero del convento (ayudante consciente) y a Violante de Alarcón (ayudante inconsciente), convirtiéndose en una especie de lector voyeurista de la vida privada que las cartas contienen. La captura del secreto de la correspondencia entre la joven Malsira y Laramonte encierra un problema de máximo interés. El capitán realista copia "con bien imitada letra, la carta de Laramonte [...] guardando el original" (II, p. 263), en un gesto que puede interpretarse como mimético y acaso también como una traducción, pues el copista asume el lugar del emisor de la carta, sustituyéndolo, y conserva el original para aumentar el archivo policial. La copia de la carta indudablemente carece del valor de autenticidad que el original posee; porta en su materialidad ("bien imitada letra") la huella del otro, que ve sin ser visto e ingresa al mundo de los amantes, haciendo más evidente la distancia o la ausencia que se establece entre el emisor y el destinatario de la carta ${ }^{18}$. San Bruno se apodera así, en su calidad de lector y copista, del secreto que atesora la carta. Él percibe secretamente el secreto y no puede ser de otro modo, pues "la importancia es que la percepción del secreto solo puede ser a su vez secreta: el espía, el mirón, el chantajista, el autor de cartas anónimas son tan secretos como los que tienen que descubrir, cualquiera que sea su finalidad ulterior" (Deleuze; Guattari, 1997, p. 287). Capturar el secreto contenido en la enunciación de las vidas privadas a partir de la transfiguración del policía torturador en lector y copista se convierte en expresión del deseo perverso de San Bruno, quien, debido a sus ansias de capturar secretos, deviene incluso en un infame sacerdote confesor: "Tiene usted razón, señora [le habla a Violante de Alarcón]. En asuntos del servicio soy como un confesor" (II, p. 496).

Resulta interesante advertir que en el encuentro entre el fanático don Vicente y la escritura epistolar predomina la incomprensión de las palabras del discurso amoroso, que le parecen soberanamente ridículas: "El capitán siguió leyendo y encontrando cada vez más huecas y sin sentido esas frases de la eterna cantinela del amor, que no tienen armonías sino para el corazón que las entona y para el corazón que las inspira. Mas para él, que vivía entre dos fanatismos: como antiguo fraile, el de Dios; como guerrero, el del rey, todo aquello le parecía soberanamente ridículo" (I, p. 263). La incomprensión y la ridiculez de las palabras, como advierte Fernando Pessoa cuando señala que "las cartas

\footnotetext{
${ }^{18}$ Esto nos recuerda otra vez a Todorov, quien sostiene en su análisis de Las amistades peligrosas que "el receptor de un mensaje escrito es indefinido en lo posible: ¿Cómo prever quién es el que va a leer un texto, y si alguien lo va a leer alguna vez?" (1971, p. 33).
} 
de amor, si hay amor, / tienen que ser / ridículas. // Pero, al fin y al cabo, / solo las criaturas que nunca escribieron cartas de amor / sí que son ridículas.” (1990, p. 307), cifran la distancia irreductible que se expresa entre el mundo binario que rige al capitán y que puede visualizarse en los recortes de realidad que establece, por ejemplo, la construcción del adversario como un otro radical, como perros insurgentes a los que es necesario perseguir, humillar y exterminar. No es posible para él ingresar a las zonas intermedias, desestructurantes de binarismos, que actualizan las palabras amorosas que se dirigen los amantes provenientes de mundos diferentes y en conflicto. La escritura y lectura del soldado se orienta más bien hacia la codificada escritura de la guerra. El discurso del capitán es el de las ordenanzas, bandos, proclamas, oficios, mandatos, salvoconductos: escrituras regidas por palabras que conjuran el odio, la mentira y la violencia; por palabras creadoras de una cisura que impide el hallazgo del otro y que articulan verdaderas sentencias de muerte; palabras diferentes, en todo sentido, a las que dirigen un llamado y una invitación al encuentro con el otro como ocurre con las palabras de vida de las cartas de amor. Durante la Reconquista, desde esta perspectiva, revela una guerra linguística, que no se limita a la retórica de la guerra, en la que los dispositivos escriturales de la guerra, previamente mencionados, colisionan con el dispositivo carta. La fuerza del secreto y del amor resiste la violencia del hombre contra el hombre, siempre repudiada por Blest Gana, que impera en el mundo ficcionalizado.

La captura del secreto no solo se expresa en la relación entre Trinidad y Laramonte, pues San Bruno, con la ayuda de Juan Argomedo, primero, y del soldado Astudillo, después ${ }^{19}$, intercepta las cartas que envía desde prisión Alejandro Malsira, las que, como indica el narrador, tienen un estilo "sereno", "sobrio" y "tranquilizador", y las cartas que envía doña Clarisa. Nos interesa la reflexión de San Bruno, enunciada por la voz del narrador, que surge luego de leer las cartas del prisionero político y de su esposa:

Uno y otro sufrían: esto era lo principal para don Vicente. La varonil entereza del marido y el desconsuelo profundo de la mujer le ofrecían igual contentamiento. El patricio orgulloso tendría que humillarse. La agobiada esposa tendría que seguir llorando. Ambos servirían como ejemplo a los que tuviesen la tentación de rebelarse contra la segunda autoridad del monarca. Esa era la lógica de San Bruno. Estrecha como un instrumento de tortura, ella debía hacer trizas cuanto le resistiese. Y así seguía, saboreando la lectura (I, p. 338).

\footnotetext{
${ }^{19}$ Recuérdese que la red que San Bruno teje sobre Alejandro Malsira y los otros presos políticos requiere, en primer lugar, la intervención de Juan Argomedo y del soldado Astudillo, quienes son ayudantes en el proyecto de captar el secreto de la correspondencia, y, en segundo lugar, del cabo Villalobos, quien finge apoyar a los reos políticos para que se fuguen de la prisión y participen en un levantamiento cívico-militar, lo que traerá como consecuencia la muerte de Alejandro Malsira.
}

182 | AlpHA No 53 (DiCIEMBRE 2021) PÁGS. 169-189. ISSN 07 16-4254 
San Bruno advierte el sufrimiento de Clarisa Bustos y de su esposo, y experimenta placer al leer la carta ${ }^{20}$. El ejercicio del poder implica no solo la represión del placer del otro, sino que también, como lo ha señalado Michel Foucault en Vigilar y castigar (2000), implica la obtención de un placer como el que revela la perversión del capitán. Según Gotschlich (1992), San Bruno es un personaje focal, que procura perpetuar el conflicto entre españoles y criollos. Agregamos que este personaje, caracterizado por su "fecundo ingenio para hacer el mal, con su método de ordenancista, que no dejaba nada a cargo de la casualidad" (I, p. 401), se convierte en cifra del poder y del mal absoluto en la novela de Blest Gana, precisamente porque siente placer con el sufrimiento del otro.

San Bruno lidera una máquina policial compleja ${ }^{21}$, compuesta por espías que se procuraba "para recoger noticias, indagar secretos y penetrar en las casas de los insurgentes" (I, p. 248), que opera sobre todo el entramado ficcionalizado, creando el clima de terror que le es característico ${ }^{22}$. Su objetivo es siempre identificar y capturar la verdad del secreto. Integra una máquina binaria de captura y divulgación del secreto ${ }^{23}$, por lo que las cartas, lugar por excelencia del secreto, iluminan una guerra subterránea que se actualiza entre el lenguaje, el secreto y el poder, cuestión que sabe San Bruno, pero también Manuel Rodríguez, quien advierte a Abel Malsira en el capítulo XVII de la segunda parte de la novela, que "las cartas son terribles denunciadoras que revelan su secreto a todo el que se apodera de ellas" (II, p.367). Las cartas, en efecto, ocupan lugares

\footnotetext{
${ }^{20}$ En este mismo sentido puede comprenderse el placer lujurioso de San Bruno, cuando intenta conocer el paradero de Malsira y de Rodríguez mediante la tortura de Luisa Bustos: "San Bruno, con ávidos ojos, en un delirio de sensualidad turbulenta, miraba avanzar la tortura de infamia. El corpiño, desabrochado, poco a poco, había descubierto la riqueza ofuscadora del pecho, la virginal firmeza de los suaves contornos, la deslumbradora tersidad del cutis; un busto de proporciones esculturales, la pomposa poesía de la materia convertida en un sueño de idealismo profano" (II, p. 452).

${ }^{21}$ Hay dos formas de ejercicio del poder que interactúan en la novela y es posible distinguir en los métodos de captura del secreto que despliega San Bruno: la tortura y la interceptación de cartas. Las torturas, que hacen surgir un saber y una verdad a partir de la violencia sobre el cuerpo del supliciado, pertenecen a un modo espectacular de manifestación del poder, que es propia de las sociedades de soberanía según los planteamientos de Michel Foucault (2000). La interceptación de cartas obedece, en cambio, a un ejercicio distinto del poder, que relacionamos más bien con las sociedades disciplinarias descritas por Foucault (2000), en la medida en que la visibilidad y la espectacularidad del poder de las sociedades de soberanía son desplazadas por la invisibilidad de una "maquinita" policial y por el registro detallado de quienes resisten el poder dominante.

${ }^{22}$ En la carta que envía Luisa Bustos a Abel Malsira, contenida en el capítulo LI de la segunda parte de la novela, leemos: "el sistema de espionaje puesto en planta por San Bruno, cada día más feroz contra los patriotas, puede convertir en crimen las más inocentes conversaciones en que se hable de lo que pasa, se llega a desconfiar hasta de los sirvientes" (II, p. 267).

${ }^{23}$ El secreto será divulgado en el momento y lugar en que lo determine la inteligencia diabólica del capitán realista, como puede observarse, por ejemplo, cuando comparte el secreto de los amores de Trinidad y Laramonte con don Jaime Bustos, el pusilánime hermano de Clarisa Bustos. San Bruno divulga el secreto a Jaime Bustos, quien es tocado en su vanidad, para desarrollar su plan de venganza contra Laramonte y deshacer una unión intolerable para su sistema de pensamiento binario: "pero esto que voy a decirle es un secreto de Estado, ¿entiende usted?, un verdadero secreto de Estado, y un secreto de su familia de usted al mismo tiempo" (II, p. 103).
}

AlPHA No 53 (DiCIEMBRE 2021) PÁGS. 169-189. ISSN 07 16-4254| 183 
claves en el entramado novelesco e inciden en la producción de sentidos. Apropiarse del secreto, desde esta perspectiva, implica ejercer un determinado poder en el espacio ficcionalizado ${ }^{24}$.

Durante la Reconquista textualiza las relaciones intensas entre secreto y poder, las que no se restringen únicamente a la figura por antonomasia del ejercicio autoritario y violento del poder realista, San Bruno, personaje "sombrío e impenetrable, rígido como un enigma, el rostro inmóvil que guarda en su cerebro de granito el secreto de las debilidades humanas" (II, p.166), quien se encumbra incluso por sobre los afectados y vanidosos Mariano Osorio y Marcó del Pont. Hay otros personajes que se singularizan por su afán de capturar secretos, tales como José Retamo, "hombre a quien [según la opinión general] se confían secretos de Estado y que sabe guardarlos" (I, p. 91); las primas Catita y Cleta, verdaderas arpías cazadoras de secretos, que ven sin ser vistas, a quienes "la sospecha de una intriga amorosa las hacía rejuvenecerse" (II, p. 95). Otros personajes conocen secretos, sin recurrir a un sistema de espionaje. Manuel Rodríguez sabe el secreto del amor de Luisa Bustos por Abel Malsira y sabe también que su amigo debe acoger este amor y olvidar a Violante de Alarcón; Luisa Bustos conoce el secreto del amor de Trinidad y también el secreto de su tío Jaime Bustos ${ }^{25}$, a quien le pide que no lo explicite cuando los arrebatos de la pasión son para él incontenibles: “¡Vaya, tío, ya está con sus misterios! Déjese de secretos, yo no quiero saber los secretos"(I, p. 114). El secreto, como hemos sugerido, se filtra por todas partes y alcanza a los otros, a quienes contagia y transfigura. En las relaciones que los personajes establecen con el secreto y el poder, pareciera ser clave, por una parte, saber guardar secretamente los secretos. Personajes como Retama, Jaime Bustos, Juan Argomedo, Ña Peta, por ejemplo, no saben guardar secretos. Sí sabe guardar secretamente el secreto Luisa Bustos, la heroína de la novela, quien es torturada y no revela el secreto del paradero de Manuel Rodríguez y Abel Malsira. El secreto en Durante la reconquista, así como también se expresará en Gladys

\footnotetext{
${ }^{24}$ Merece atención el falso secreto contenido en las cartas firmadas por Isidro Meza y Lorenzo Carraquín, que traen desde Mendoza Álvarez Condarco y Manuel Rodríguez, con el objetivo de engañar a San Bruno y los realistas, ocultando los verdaderos planes de los patriotas. El verdadero secreto, ilegible en este caso, difiere del secreto contenido en las cartas y no puede ser interceptado por la máquina de vigilancia estatal. La derrota del poder es evidente en este sentido y convierte a los patriotas, representados por Manuel Rodríguez, quien deviene personaje secreto gracias a su habilidad para disfrazarse y transfigurarse en un otro inadvertido, en una fuerza que secretamente fragua su venganza. El plan de Rodríguez, luego de su retorno a Chile, es "un movimiento simultáneo en diversos puntos del país. [Ése] era su secreto (II, p. 304).

${ }^{25}$ Jaime Bustos, en realidad, cree tener un secreto de amor, pero él no posee las características de quienes saben guardar secretos y penetrar en el juego de relaciones entre secreto y poder de la novela. Todos en Santiago conocen, en efecto, su deseo de casarse con Luisa Bustos: "En Santiago se empezaba a hablar de eso. A ellas [prima Catita y prima Cleta] se lo había preguntado el mocho de la Recoleta cuando había venido a pedir limosna" (II, p. 124).
} 
Fairfield (1912), la última novela de Blest Gana, tiene rostro de mujer. Luisa Bustos, en efecto, es quien "posee el secreto y el poder" (I, p. 234). Ella escribe una carta de la que, a continuación, nos ocuparemos.

\section{V.EL SECRETO DE LUISA BUSTOS}

La extensa carta que envía Luisa Bustos a Abel Malsira, personaje soñador y débil que habita los territorios del amor romántico (que nunca quedan del todo desplazados por los territorios de la guerra que acoge luego de la muerte de su padre), se encuentra en el capítulo LI del segundo tomo de la novela. La carta, como indica el narrador, fue "escrita día a día durante las horas de soledad y recogimiento" (II, p. 260), y se constituye en un "examen de conciencia" (II, p. 260), una "meditación solitaria" (II, p. 261), "una larga conversación con el ausente" (II, p. 268); por tanto, como destaca Gotschlich (1991, p. 52), es un efectivo retrato del estado interior de Luisa. La escritura deviene, entonces, en posibilidad de rememoración de situaciones vividas, relación de uno consigo mismo, autoexamen, confesión dolorosa ante el propio rostro que se proyecta sobre una materialidad, el papel, "confidente mudo" (II, p. 260) de los secretos del alma exaltada de la escribiente; pero también se constituye en una práctica escritural terapéutica que alivia a Luisa Bustos del peso que implica conservar por largo tiempo un secreto. Michel Foucault en Hermenéutica del sujeto (2005) destaca la relación existente entre el cuidado de uno mismo y la medicina, y señala que la práctica de uno mismo, que reconocemos en la escritura epistolar, puede ser concebida como un acto médico, terapéutico, precisamente la consecuencia que tiene la escritura de la carta en la interioridad de Luisa Bustos.

El contenido de la carta puede separarse, a grandes rasgos, en dos partes. En la primera, que se orienta más bien al ámbito familiar y de la intimidad del yo, encontramos la noticia del viaje a Perú de Laramonte, el recuerdo de la desgraciada muerte de Trinidad y la revelación de los secretos de Luisa Bustos. En la segunda parte encontramos noticias referidas al ámbito político. Luisa señala a Abel que son "cosas que pueden interesarle y distraerlo en su soledad" (II, p.265), por lo que estamos ante una escritura metatextual que busca orientar la recepción del destinatario. Las noticias se refieren a las fuerzas de resistencia de los patriotas y su falta de liderazgo; la necesidad del retorno de Manuel Rodríguez y de la creación de una montonera; el cambio en la presidencia y el arribo de Marcó del Pont, quien gobierna por la intimidación; el clima de terror dominante en Santiago; la "indignación y [el] deseo de venganza que se deja sentir entre caballeros y pueblo" (II, p.267); el inminente remate de la hacienda "Los Canelos"; el lugar en donde están ocultos el dinero y las armas que Alejandro Malsira ha dispuesto para un levantamiento contra las fuerzas realistas; el anuncio del contenido de la carta adjunta de Beno Carpesano; y noticias acerca de los hermanos pequeños de Malsira. La carta permite recordar acontecimientos vividos, a la vez que anticipa situaciones que se desarrollarán en los capítulos siguientes de la novela. 
En ambos momentos de la carta advertimos cómo la perspectiva del personaje se entrelaza con la perspectiva del narrador, quien interviene entregando datos y emitiendo comentarios respecto de la carta de Luisa. La carta revela, como indica Gotschlich, la presencia de una dualidad de voces, en la que el narrador "ordena con rasgo interpretativo rasgos del discurso" (1991, p. 51), convirtiéndose en una "voz paralela y alternativa" (1991, p. 52). Este procedimiento es fundamental, como ya hemos sugerido, en Durante la Reconquista y permite advertirque estamos ante un narrador implicado, es decir, "un sujeto participante y comprometido, no distanciado" (Spang, 1998, p. 67), el que, además de incidir en la interpretación de la historia ficcionalizada, controla que la irrupción de nuevos narradores (emisores de cartas) no genere un exceso de perspectivas ni afecte la ilusión de realidad de la ficción novelesca. El narrador, que se confunde con el autor implícito, en la medida en que ejerce un control sobre lo textualizado, incide, como planteamos previamente, en la construcción del lector implícito y, por consiguiente, en los efectos que se buscan producir en el lector real, a quien se interpela para que examine un tiempo pasado, en el que los sueños (liberales), agostados a fines del siglo XIX, encontraron sus bases fundamentales. Volvamos a la carta escrita por Luisa Bustos, la que, según Gotschlich, se constituye en un microtexto de máximo interés en la novela de Blest Gana:

Que un microtexto refleje en muchos planos al macrotexto, tipos de lenguajes, alternativas de perspectivas, relación informativa de situaciones personales, costumbristas, históricas, interpretación de hechos, alusión a las formas mismas de desplegar y ocultar datos e información y reflexión sobre el acto de escribir, parecen exceder la forma canónica de la novela realista. La misiva es una síntesis de momentos puntuales pero significativos de la vertiginosa ocurrencia e intensidad del curso histórico, del despertar indesmentible de la conciencia patriótica y del dolor concreto de la imposición de la fuerza y el terror (Gotschlich, 1991, p. 54).

Henry James sostiene en El arte de la novela que "una novela es una cosa viva, uno y continuo como cualquier otro organismo, y en la medida en que esté viva veremos que en cada parte hay algo de cada una de las otras partes" (2016, p. 20). En efecto, la novela es un organismo y todas sus partes se conectan y dialogan. En el caso de la carta de Luisa, comentada con claridad y precisión por Gotschlich, se advierte cómo este dispositivo escritural, desde la perspectiva de la emisora y las intervenciones del narrador, produce un tejido que conecta hacia atrás y hacia adelante las formas y el argumento de la novela.

El examen de la primera parte de la carta nos permite continuar reflexionando, pues es el lugar textual en donde se pone en conocimiento al destinatario de los dos secretos de Luisa: el del ataque sexual de Juan Argomedo, que trae como consecuencia la solicitud de matrimonio de don Jaime Bustos, a quien Luisa respeta profundamente, y el secreto de su amor por Abel Malsira, que no ha podido ser revelado antes por la afrenta de Argomedo, la pasión de Malsira por Violante de Alarcón y la postergación del amor 
pasión en función del proyecto patriótico que la joven abraza. El primero es enunciado de manera explícita, por lo que queda develado en una primera lectura literal de la carta, cumpliendo de este modo con la promesa que la joven realizó a Malsira, antes de que este partiera a su destierro en Mendoza. La historia de dolor y de vergüenza, anticipada por el narrador en uno de los comentarios que realiza de la carta, la refiere Luisa, omitiendo "los detalles ofensivos a su pudor" (II, p. 264) ${ }^{26}$. El segundo secreto está oculto en los intersticios de la letra, por lo que solo puede descubrirse a partir de una lectura que penetra más allá del sentido literal. Operaciones en el lenguaje permiten decir el secreto sin que el destinatario "pueda comprenderlo" (II, p. 261). Recurre para ello a una enunciación en la que el emisor deja de ser individual y deviene colectivo, pues Luisa escribe por ella y por su tía: "lo hemos tenido en nuestro pensamiento a todas horas" (II, p. 259-260). Lenguaje del disimulo, de la contención y del velamiento de un secreto, que conoce Manuel Rodríguez, pero también el lector implícito de la novela, quien posee las facultades para reconocer algunos lugares claves (indicios) de la escritura de la signataria, convirtiéndose así en un lector privilegiado de la carta: "su pudor empleaba ingenuas precauciones de lenguaje, para dar una forma indecisa a las confesiones que le hacía el corazón" (II, p. 260). El secreto, desde esta perspectiva, es interior al lenguaje: refiere al lenguaje mismo de la carta.

Durante la reconquista revisita el pasado para recoger las lecciones olvidadas, sin las cuales el presente se vuelve menos comprensible y pareciera clausurarse el porvenir, y convierte la carta en el territorio del secreto, que es asediado de manera sistemática por el poder. La guerra contra el secreto y por el secreto se constituye así en una dimensión clave de la novela: "las noticias que suelen venir de la otra banda se comunican en secreto entre las familias y mantienen nuestra esperanza" (II, p. 265). Una comunidad, pareciera decirnos secretamente Blest Gana, se encuentra ligada, al igual que la literatura, por un secreto, por un secreto amoroso, donde resisten una promesa y una destinación.

\footnotetext{
${ }^{26}$ Luisa Bustos no solo omite información en la primera parte de la carta. Lo hace también en la segunda parte. Esta nueva omisión la conocemos por la carta que Beno Carpesano envía a Abel Malsira. En ella, además de informar de los resultados afrentosos que tuvo la puesta en escena de la comedia "La olla de Mazamorra o contra basura, escoba" (que revela cómo la resistencia artística y el poder del humor pueden erosionar y hacer reaccionar al poder dominante) y el deseo de unirse a la lucha de los patriotas (que cifra un cambio de actitud de los hermanos Carpesano, quienes no se interesaban por asuntos políticos), se informa de los flirteos amorosos entre Violante de Alarcón y Casimiro Marcó del Pont, y el interés de esta por comprar la hacienda "Los Canelos". La omisión de estas noticias en la carta de Luisa Bustos sugiere la exclusión de Violante de Alarcón, la coqueta rival de Luisa Bustos, del espacio de la escritura, el que solo admite el diálogo diferido de los amantes ausentes, quienes se reúnen imaginariamente en los territorios de la carta.
} 
Este artículo fue escrito dentro del marco del Proyecto Fondecyt $\mathrm{N}^{\circ} 1171498$

"Sentidos, formas y figuraciones del mal en la novela chilena producida entre 1858 y $1929 "$.

\section{OBRAS CITADAS}

Alegría, Fernando (1978). Aspectos fundamentales de la novela romántica latinoamericana, en Mirta Yáñez (compilación y prólogo). Recopilación de textos sobre la novela romántica latinoamericana. (pp. 61-128). Casa de las Américas.

Amunátegui, Domingo (1915). Bosquejo histórico de la literatura chilena. Revista Chilena de Historia y Geografía. Imprenta Universitaria.

Araya, Guillermo (1987). Alberto Blest Gana, en Luis Íñigo Madrigal (Coordinador). Historia de la literatura hispanoamericana. Tomo II. Del neoclasicismo al modernismo. Cátedra.

Bajtin, Mijail (1979). El problema de los géneros discursivos. En Estética de la creación verbal. Siglo Veintiuno Editores.

Blest Gana, Alberto (1946). Durante la Reconquista. Tomos I y II. Zig-Zag.

Carson, Anne (2015). Eros. El dulce-amargo. Fiordo.

Chartier, Roger (2007). La historia o la lectura en el tiempo. Gedisa.

Concha, Jaime (1977). Prólogo. Alberto Blest Gana. Martín Rivas. Biblioteca Ayacucho: IX-XL.

Deleuze, Gilles; Guattari, Félix (1997). Mil mesetas. Capitalismo y esquizofrenia. Pre-Textos.

Dickinson, Emily (2001). Algunos poemas. La Veleta.

Doll, Darcie (2002). La carta privada como práctica discursiva. Algunos rasgos característicos, en Revista Signos, vol. 35, No 51-52: 33-57.

Foucault, Michel (2005). La hermenéutica del sujeto. Akal.

— (2000). Vigilar y castigar. Siglo Veintiuno de España Editores.

— (1996). La vida de los hombres infames. Caronte Ensayos.

Genette, Gerard (1989). Palimpsestos. La literatura en segundo grado. Taurus.

Gotschlich, Guillermo (1991). Alberto Blest Gana y su novela histórica. Revista Chilena de Literatura, № 38: 29-58.

Hossiason, Laura Janina (2017). Siete novelas de Blest Gana: Una visión de conjunto, en Revista Chilena de Literatura, $\mathrm{N}^{\circ}$ 96: 235-258.

Iser, Wolfgang (1987). El acto de leer. Taurus.

James, Henry (2016). El arte de la novela y otros ensayos. Ediciones Coyoacán.

Jitrik, Noé (1995). Historia e imaginación literaria. Las posibilidades de un género. Editorial Biblos. 
Kaempfer, Álvaro. (2006). "La sutura legible y subalterna de la ficción histórica de la chilenidad en Durante la Reconquista (1897) de Alberto Blest Gana". Atenea, $\mathrm{N}^{\mathrm{o}}$ 494: 143-159.

Lastra, Pedro. (2009). Alberto Blest Gana. Durante la reconquista. Edición dispuesta y anotada por Iván Jaksic y Juan Durán Luzio. Universitaria, Alpha, № 28: 260-263.

Mata, Carlos (1998). Retrospectiva sobre la evolución de la novela histórica, en Kurt Spang, Ignacio Arellano y Carlos Mata (editores). La novela histórica. Teoría y comentarios. Ediciones Universidad de Navarra: 51-87.

Melfi, Domingo (1938). Estudios sobre literatura chilena. Nascimento.

Montes Capó, Cristián (2004) El metarrelato nacionalista en Martín Rivas de Alberto Blest Gana, en Anales de Literatura Chilena, $\mathrm{N}^{\circ}$ 5, 3-27.

Moraña, Mabel (2014). Inscripciones críticas. Ensayos sobre cultura latinoamericana. Cuarto Propio.

Navarrete, Carolina (2017). Las afecciones de la carta. Sujeto doliente y resistencia en la escritura epistolar de mujeres en Chile en los siglos XVIII y XIX. Cuarto Propio.

Pessoa, Fernando (1990). Pessoa. Obra poética. Tomo II. Ediciones 29.

Poblete, Hernán (1955). Alberto Blest Gana y su obra. Pehuén.

Ricoeur, Paul (2007). El mal. Un desafio a la filosofía y a la teología. Amorrortu.

Salinas, René (2006). La pareja: comportamientos, afectos, sentimientos y pasiones, en Rafael Sagredo y Cristián Gazmuri (coordinadores). Historia de la vida privada en Chile. Tomo 2. El Chile moderno de 1840 a 1925. Taurus.

Schoennenbeck, Sebastián. (2013). Paisaje, nación y representación del sujeto popular. Visiones de un Chile imaginado. Aisthesis, $\mathrm{N}^{\circ}$ 55: 73-94.

Silva Castro, Raúl. (1955) Alberto Blest Gana. Zig-Zag.

Sommer, Doris 2004. Ficciones fundacionales. Las novelas nacionales en América Latina. Fondo de Cultura Económica.

Spang, Kurt (1998). Apuntes para una definición de la novela histórica, en Kurt Spang, Ignacio Arellano y Carlos Mata (editores). La novela histórica. Teoría y comentarios. Ediciones Universidad de Navarra: 51-87.

Todorov, Tzvetan (1971). Literatura y significación. Editorial Planeta.

Vergara, Sergio (1987). Cartas de mujeres en Chile, 1630-1885. Editorial Andrés Bello.

Violi, Patrizia (1987). La intimidad de la ausencia: formas de la escritura epistolar. Revista de Occidente, $\mathrm{N}^{\mathrm{o}}$ 68: 87-96.

Viu, Antonia (2011). Reseña de Durante la Reconquista. Anales de Literatura Chilena, $N^{\circ} 15: 235-247$. 